\title{
Biological behavior of keratoacanthoma and squamous cell carcinoma: telomerase activity and COX-2 as potential markers
}

\author{
Thomas C Putti, Ming Teh and Yoke S Lee \\ Department of Pathology, National University of Singapore, Republic of Singapore
}

\begin{abstract}
Distinguishing keratoacanthoma from squamous cell carcinoma is a persistent issue in pathology practice. Solitary keratoacanthoma is a self-limiting lesion as opposed to rather aggressive clinical behavior of squamous cell carcinoma. Several markers were studied to understand their biology and to separate these two lesions on a firm basis, but without much success. In this study, we plan to utilize recent markers such as telomerase activity and cyclooxygenase-2 (COX-2) along with more established marker p53 in understanding the biologic differences between keratoacanthoma and squamous cell carcinoma. We studied 17 well to moderately differentiated squamous cell carcinoma and 24 early proliferative phase keratoacanthoma by immunohistochemistry for the expression of p53 protein, COX-2 and telomerase activity. Higher telomerase activity was found in $11 / 17$ squamous cell carcinoma $(65 \%)$ compared to $4 / 24(17 \%)$ of keratoacanthoma. Similarly, stronger expression of p53 and COX-2 was detected in $12(71 \%)$ and $11(65 \%)$ cases of squamous cell carcinoma compared to $2(8 \%)$ and $2(8 \%)$ cases of keratoacanthoma respectively. A highly significant ' $P$ ' value was obtained for telomerase activity (0.001), p53 (0.000), and COX-2 (0.001). Telomerase activity, COX-2, and p53 expression provide evidence that keratoacanthoma and squamous cell carcinoma are indeed distinct entities and also help in discriminating these two lesions, which closely resemble each other on conventional morphology. Although these markers present new insights into the biologic variation of keratoacanthoma and squamous cell carcinoma, they are of limited value for routine application in histological distinction of these two lesions. The differential expression of markers also explains the sustained proliferation observed in squamous cell carcinoma, compared to a shorter lifespan and involution in keratoacanthoma.

Modern Pathology (2004) 17, 468-475, advance online publication, 13 February 2004; doi:10.1038/modpathol.3800063
\end{abstract}

Keywords: keratoacanthoma; squamous cell carcinoma; telomerase; p53; cyclooxygenase-2; immunohistochemistry

Keratoacanthoma is typically a self-healing, rapid onset skin lesion, with a dome-shaped keratin-filled crater, whereas cutaneous squamous cell carcinoma is conventionally a malignant lesion with cellular atypia and stromal invasion that progresses continuously without spontaneous resolution. ${ }^{1,2}$ The distinction of keratoacanthoma from squamous cell carcinoma on histological grounds is a matter of convention for a long time and some even claim that keratoacanthoma is a variant of squamous cell carcinoma or progresses into squamous cell carcinoma. ${ }^{3,4}$ Several publications came up with different criteria to differentiate between these two lesions. Cribier et $a l^{5}$ independently studied a large cohort of

Correspondence: Dr T C Putti, MD, Diplomate (Am.B.Path), Department of Pathology, National University Hospital, 5, Lower Kent Ridge Road, Singapore 119074, Republic of Singapore.

E-mail: pattcp@nus.edu.sg

Received 17 June 2003; revised 29 October 2003; accepted 11 November 2003; published online 13 February 2004 squamous cell carcinoma and keratoacanthoma. The study, based on 14 architectural criteria concluded that none of these criteria were reliable and in the presence of atypical features or difficulty in diagnosis, they should be treated as squamous cell carcinoma. As the clinical behavior and prognosis are different for these two lesions, there must be a reliable way to differentiate them. In most of the cases, poorly differentiated squamous cell carcinoma can be easily distinguished from keratoacanthoma, while distinction between keratoacanthoma and well-differentiated squamous cell carcinoma is a problem. Several studies sought to answer this question but none of them proved to be conclusive. These include DNA cytometry, ${ }^{6}$ p53 expression, ${ }^{6-8}$ proliferating cell nuclear antigen (PCNA), ${ }^{9}$ desmosomal glycoproteins, ${ }^{10,11}$ mitotic cyclins,${ }^{12}$ oncostatin $\mathrm{M},{ }^{13}$ sialyl-Tn antigen expression, ${ }^{14}$ syndecan- $1,{ }^{15}$ angiotensin type-1 (AT1) receptors, ${ }^{16}$ and comparative genomic hybridization. ${ }^{17}$ In the present study, we examined the role of recently described markers 
such as telomerase activity and cyclooxygenase-2 (COX-2) along with conventional marker p53 in understanding their biologic behavior and distinguishing keratoacanthoma from squamous cell carcinoma cases. Literature search shows no published data evaluating the role of telomerase activity and COX-2 expression in distinguishing keratoacanthoma from squamous cell carcinoma. These markers were selected as they represent newer diagnostic tools, not yet applied in defining differences between these two lesions. p53, a tumor suppressor gene, was also included in the study to identify the frequency of mutated gene product in the two entities and also to examine any new trends in contrast to earlier observations. ${ }^{6-8}$

Telomeres are specialized structures at the ends of eukaryotic chromosomes that play a pivotal role in chromosome protection, positioning, and replication. ${ }^{18}$ Telomerase is a ribonucleoprotein that synthesizes telomeric DNA onto chromosomal ends, playing a vital role in cellular proliferation and tumorigenesis. As the normal somatic cell divides, there is a corresponding shortening of telomeres, thus acting as a mitotic clock by which cells count their divisions. The results of several studies suggest that telomerase activity is directly involved in telomere maintenance, linking this enzyme to immortality. Telomerase expression represents a critical step in tumorigenesis because it overcomes the limitations of catastrophic telomere loss and its activity is present in most of the human tumors including skin cancers. ${ }^{19,20}$

COX, or prostaglandin $\mathrm{H}$ synthase, is a key enzyme in the synthesis of prostaglandins (PGs). Two related but unique isoforms of COX, COX-1 and COX-2, have been identified. COX-1, a housekeeping enzyme, is expressed constitutively on the cell membranes in most tissues and appears to be responsible for the production of $\mathrm{PGs}$ that mediate normal physiologic functions. COX-2, in contrast, is undetectable in most normal tissues. COX-2 enzyme can be induced by interleukin-1, epidermal growth factor, transforming growth factor-beta, tumor necrosis factor-alpha, and inducible nitric oxide synthase and therefore contributing to the synthesis of PGs in inflamed and neoplastic tissues. ${ }^{21,22}$ In fact, human neoplasms that overexpress COX-2 produce more prostanoids (particularly PGE2) than healthy tissues from which the tumors are derived. COX-2 overexpression has been detected in various premalignant and malignant tissues, including oral leukoplakia and squamous carcinoma of the head and neck. ${ }^{23}$ There is increasing evidence to show that COX-2 has an important role in carcinogenesis. The evidence comes from COX-2 overexpression in tumor tissues and the inhibition of cancer development in animal models. ${ }^{23}$

The p53 gene, a tumor suppressor, is involved in the onset of several malignancies and also the most significant genetic alteration. ${ }^{24}$ Wild $p 53$ is a mediator of tumor suppression, whereas mutated product losses this function. Mutated p53 gene product accumulates in large amounts in the nucleus and can be easily identified by immunohistochemical methods. A few studies show a significant trend in p53 immunopositivity from keratoacanthoma to squamous cell carcinoma and also variable distribution pattern. ${ }^{7,8}$ Mutation studies of the p53 gene confirm a higher incidence of mutations in squamous cell carcinoma, in contrast to keratoacanthoma. ${ }^{25,26}$

\section{Materials and methods}

A total of 17 cases of well to moderately differentiated cutaneous squamous cell carcinoma and 24 early phase keratoacanthoma were retrieved from the files of National University Hospital Pathology Department. Poorly differentiated squamous cell carcinomas were excluded from the study, as they posed little diagnostic problems in distinguishing from keratoacanthoma. Evolving or early phase keratoacanthoma were clinically diagnosed by a history of rapid development of an exophytic lesion with a central crater and histologically defined by the presence of a symmetrical cup-shaped proliferation of clear-to-glassy-appearing epithelium associated with strands of cells protruding into dermis (Table 1). The lesional cells display mild nuclear atypia with rare dyskeratotic cells. Squamous cell carcinomas are generally defined by lack of keratinfilled central crater, presence of stromal desmoplasia, atypical squamous cells, lack of sharp outline between tumor nests and stroma, and relatively slower onset of growth. Well-differentiated squamous cell carcinomas are characterized by the presence of several horn pearls, intercellular junctions, mature squamous cells, and rare atypicality. In contrast, moderate differentiation is defined by

Table 1 Histopathologic criteria to differentiate early keratoacanthoma from a well to moderately differentiated squamous cell carcinoma (Ackerman et $a l^{2}$ and Cribier et $a l^{5}$ )

\begin{tabular}{|c|c|}
\hline Keratoacanthoma & Squamous cell carcinoma \\
\hline $\begin{array}{l}\text { Exoendophytic lesion with a } \\
\text { central horn-filled crater }\end{array}$ & $\begin{array}{l}\text { Predominantly endophytic } \\
\text { with no horn-filled crater }\end{array}$ \\
\hline Overhanging 'lips' of epithelium & No epithelial 'lips' \\
\hline Rarely ulcerated & Commonly ulcerated \\
\hline $\begin{array}{l}\text { Abundant pale staining } \\
\text { cytoplasm of keratinocytes }\end{array}$ & Less common \\
\hline $\begin{array}{l}\text { Intraepithelial abscesses within } \\
\text { the lesion }\end{array}$ & Rare \\
\hline $\begin{array}{l}\text { Acantholytic cells within the } \\
\text { intraepithelial abscesses often }\end{array}$ & $\begin{array}{l}\text { Acantholytic cells form } \\
\text { without associated } \\
\text { neutrophils }\end{array}$ \\
\hline Gland-like formations rare & $\begin{array}{l}\text { Pseudoglandular formations } \\
\text { often }\end{array}$ \\
\hline Lack of anaplasia & Common \\
\hline $\begin{array}{l}\text { Sharp outline between tumor } \\
\text { nests and stroma }\end{array}$ & Indistinct \\
\hline Absence of stroma desmoplasia & Present \\
\hline
\end{tabular}


the presence of fewer horn pearls and conspicuous atypical cells. The hematoxylin and eosin (H\&E) slides of all these cases were independently reviewed by two pathologists (TCP and TM) and only cases with consensus were selected for further investigation. Sections of $5 \mu \mathrm{m}$ from each of the cases were cut on silane-coated slides, deparaffinized, and stained to study human telomerase reverse transcriptase activity, COX-2, and p53 oncogene expression by immunohistochemistry.

\section{Telomerase Activity by In Situ Hybridization}

Fluoresceinated oligonucleotide probes for telomerase RNA were purchased from Biogenex (San Ramon, CA, USA). For in situ hybridization $5-\mu \mathrm{m}$ sections are cut and placed on a silane-coated glass slide. After deparaffinization and rehydration in decreasing concentrations of ethanol, the sections were treated with RNAse-free proteinase $\mathrm{K}$ for $15 \mathrm{~min}$ at room temperature (RT) in a humidity chamber. Subsequently, the slides were subjected to a 5-min rinse in phosphate-buffered saline solution that contains RNAse block, followed by dehydration in a series of ethanol for $10 \mathrm{~s}$ each and air-dried. The slides were then prehybridized in a humidity chamber at $37^{\circ} \mathrm{C}$ for $60 \mathrm{~min}$, washed with two changes of $100 \%$ ethanol for $2-3 \mathrm{~min}$ each and air-dried.

Tissue sections were heated at $95^{\circ} \mathrm{C}$ for $8-10 \mathrm{~min}$ in an oven to denature the double-stranded DNA and eliminate hairpin loops or other secondary structures, prior to hybridization overnight at $37^{\circ} \mathrm{C}$ in $20-40 \mu \mathrm{l}$ of fluoresceinated probe sealed with coverslip. After hybridization, the sections are washed twice in $2 \times$ saline-sodium citrate to remove any probe that is unbound or nonspecifically bound. Subsequent immunohistochemical procedures to detect the probe includes, incubating the slides with mouse anti-fluorescein antibody, biotin-conjugated anti-mouse antibody, diaminobenzidine (DAB), and chromogen substrate solution. Sections were counterstained in eosin, dehydrated, cleared, and mounted with glass coverslips.

Specimens of human testis serve as positive controls. Appropriate negative controls and reagent controls were run by incubating nontumor tissue specimens from skin and human testis with and without probe, respectively.

\section{Immunohistochemical Staining for COX-2 and p53}

A representative slide was taken from each case and stained using standard avidin-biotin method and microwave antigen retrieval. The deparaffinized sections were heated in a microwave oven in citrate buffer, $\mathrm{pH}$ 6.0 for $20 \mathrm{~min}$. To abolish endogenous peroxidase activity, the slides were immersed in $0.6 \%$ hydrogen peroxide in methanol for $30 \mathrm{~min}$. The sections were then buffered in TRIS buffer and incubated in with normal human serum for 5 min at RT. The following primary antibodies were applied: (1) COX-2 monoclonal antibody (Catalogue No. 160112, Cayman Chemicals) at 1:500 dilution overnight at RT, (2) monoclonal mouse anti-human p53 protein (DO-7 monoclonal, DAKO) at 1:100 dilution for $1 \mathrm{~h}$ at RT. After washing in the TRIS buffer, Envision system (DAKO) was used for $30 \mathrm{~min}$ to enhance the staining, rinsed in the TRIS buffer, followed by 5 -min incubation in DAB solution. The slides were then counterstained in hematoxylin and rinsed with tap water. A known positive breast cancer tissue was used as control for p53 and COX2. The staining of cells was assessed according to both the intensity and proportion of positive cells.

\section{Evaluation of Staining Results}

Each specimen was evaluated by light microscope with estimation of the extent of immunoreactivity (population of the stained tumor cells) and staining intensity using the scoring system described below. The staining was evaluated by two pathologists (TCP and TM) in a blind fashion using light microscopy. In case of interobserver variation, a consensus score was obtained. In case of telomerase, and p53, cells with brown staining nuclei were considered positive. In contrast, COX-2-positive stain is located in the cytoplasm.

The extent of immunoreactivity was graded and scored as ' 0 point' for negative staining, ' 1 point' for $\leq 25 \%$ positive cells, ' 2 points' for $26-50 \%$ positive cells, and ' 3 points' for $>50 \%$ positivity. Based on the intensity of positive reaction in the majority of tumor cells, the intensity of staining was graded and scored as ' 1 point' for weak staining $(+)$, ' 2 points' for moderate staining $(++)$, and ' 3 points' for strong staining $(+++)$.

The overall score for each test specimen is obtained by multiplying the extent of immunoreactivity score with the intensity score. In this study, the overall score of $\geq 3$ is defined as 'strong' expression or 'high' expression and $<3$ as 'weak' expression of the antigen.

\section{Statistical Analysis}

The data were checked for normality, followed by Mann-Whitney U-nonparametric statistical analysis. A ' $P$ ' value of $<0.05$ is considered significant. The statistical tests were performed using the SPSS computer program (Version 10.0).

\section{Results}

\section{Demographics of Patients}

There were 21 male and 20 female patients with an age range of 18-93 years (median 69 years). The patients were predominantly Chinese (34 cases), followed by five cases of Malays, and two Indians. 


\section{Immunohistochemical Staining}

Among the cutaneous squamous cell carcinoma group, a positive staining (weak and strong staining) for telomerase activity was present in 17 of 17 $(100 \%)$ cases, COX-2 in 13 of 17 (76.5\%) cases, and p53 in 15 of $17(88.2 \%)$ cases (Table 2 and Figure 1). A 'strong' or higher expression of telomerase activity, p53, and COX-2 was present in $64.7,64.7$, and $52.9 \%$ of squamous cell carcinoma cases, respectively.

In comparison, the keratoacanthoma group demonstrated a positive staining for telomerase activity in 23 of 24 (95.8\%), COX-2 in eight of 24 (33.3\%) cases, and p53 in 15 of 24 (58.3\%) cases (Table 2 and

Table 2 Immunohistochemical expression of telomerase activity, COX-2, and p53 in keratoacanthoma (KA) and squamous cell carcinoma (SCC).

\begin{tabular}{lllll}
\hline & $\begin{array}{l}\text { Overall } \\
\text { expression }\end{array}$ & \multicolumn{1}{c}{$K A^{\mathrm{a}}$} & \multicolumn{1}{c}{$S C C^{\mathrm{a}}$} & 'P' value \\
& & $(\mathrm{n}=24)$ & $(\mathrm{n}=17)$ & \\
\hline \multirow{2}{*}{ Telomerase } & Negative $^{\mathrm{b}}$ & $01(4.2)$ & $0(0)$ & \\
& Weak $^{\mathrm{c}}$ & $20(83.3)$ & $06(35.3)$ & \\
& Strong $^{\mathrm{d}}$ & $03(12.5)$ & $11(64.7)$ & 0.001 \\
COX-2 & Negative & $16(66.7)$ & $04(23.5)$ & \\
& Weak & $07(29.2)$ & $04(23.5)$ & \\
& Strong & $01(4.2)$ & $09(52.9)$ & 0.001 \\
p53 & Negative & $10(41.7)$ & $02(11.8)$ & \\
& Weak & $13(54.2)$ & $04(23.5)$ & \\
& Strong & $01(4.2)$ & $11(64.7)$ & 0.000 \\
& & & & \\
\hline
\end{tabular}

${ }^{\mathrm{a}}$ Number of samples (percentage in brackets).

${ }^{\mathrm{b}}$ Negative-no staining.

${ }^{\mathrm{C}}$ Weak-Combined score of $\leq 3$.

${ }^{\mathrm{d}}$ Strong-Combined score of $>3$.
Figure 2). Similarly, a strong or high expression of telomerase activity, p53, and COX-2 was present in $12.5,4.2$, and $4.2 \%$ of keratoacanthoma cases, respectively.

A highly significant ' $P$ ' value was obtained for telomerase activity (0.001), p53 (0.000), and COX-2 (0.001) staining (Tables 2 and 3).

\section{Discussion}

Although the biologic behavior of keratoacanthoma is usually characterized by rapidly growing neoplasia, with regression in several months, there are cases subsequently presenting as metastases, especially in immunosuppressed patients. ${ }^{27}$ This has led to the controversy over whether keratoacanthoma is a distinct entity or a variant of cutaneous squamous cell carcinoma. ${ }^{3,27}$ Several studies proposed different criteria to distinguish keratoacanthoma from squamous cell carcinoma. Cribbier et $a l^{5}$ based their study on histological criteria and concluded that the distinction is impossible on histological criteria alone. A few researchers studied other methods to distinguish keratoacanthoma from squamous cell carcinoma. A high level of angiotensin type-1 receptor (AT1) was expressed in squamous cell carcinoma compared to low or no expression in keratoacanthoma in the peripheral layers. ${ }^{16}$ AT1 expression was found in suprabasal and granular layers but not detected in the basal layer. Based on these findings, the authors hypothesized that squamous cell carcinoma of the skin originates from suprabasal layer and keratoacanthoma from infundibulum of the hair follicle. Tran et $a l^{13}$ also compared immunohistochemical expression of oncostatin $\mathrm{M}$, a growth regulatory cytokine in mature

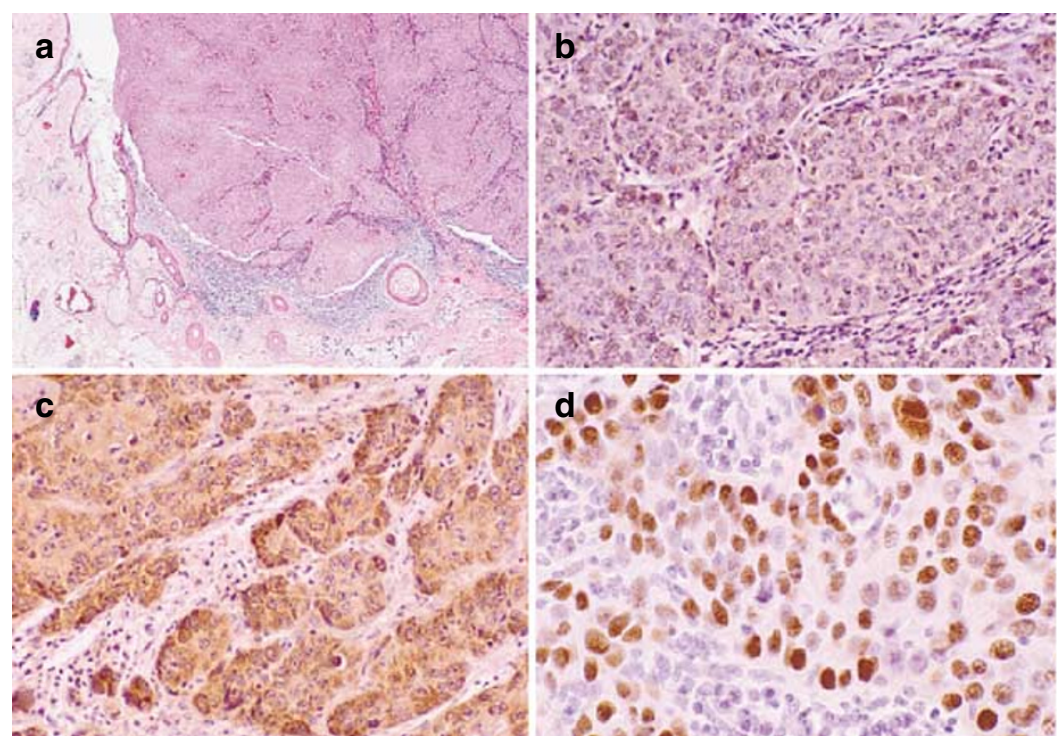

Figure 1 Selected cases of squamous cell carcinoma: (a) a representative case of moderately differentiated squamous cell carcinoma $(\mathrm{H \& E}, \times 40)$; (b) intranuclear staining for human telomerase reverse transcriptase activity $(\times 200)$; (c) intracytoplasmic COX-2 stain $(\times 200)$; $(d)$ strong intranuclear p53 expression $(\times 400)$. 


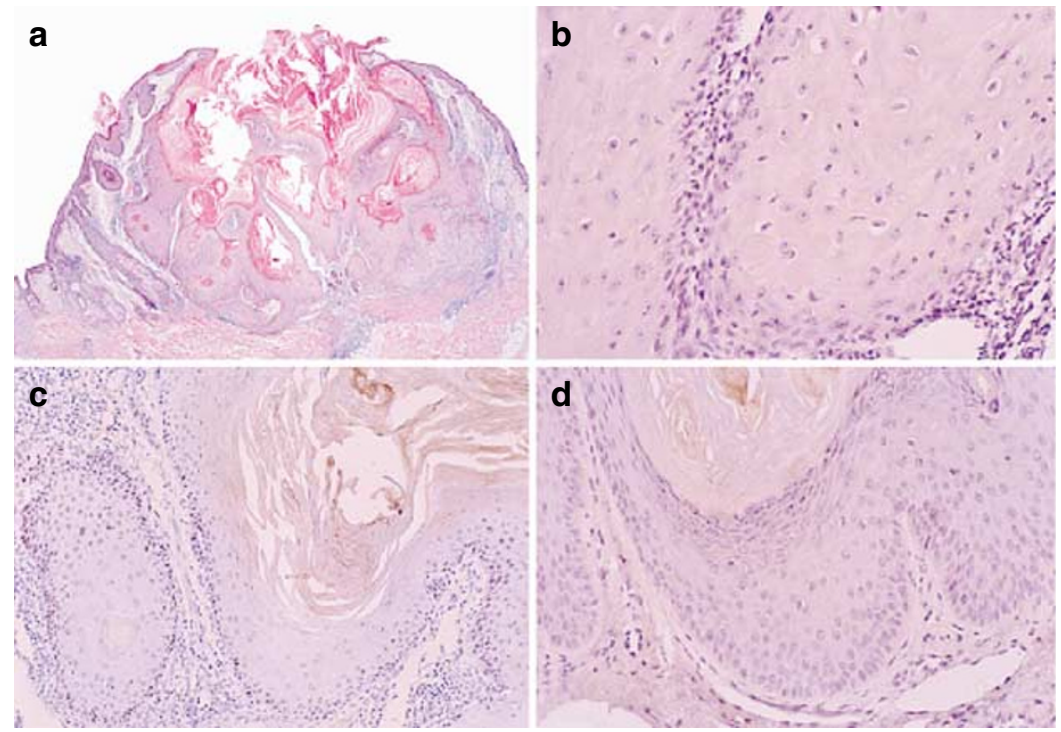

Figure 2 Selected cases of keratoacanthoma: (a) a representative case of early keratoacanthoma with overhanging lips and central hornfilled crater $(\mathrm{H} \& \mathrm{E}, \times 40)$; (b) negative for telomerase activity $(\times 400)$; (c) basal staining for p53 ( $\times 100)$; (d) negative COX-2 stain $(\times 200)$.

Table 3 Test statistics for keratoacanthoma and squamous cell carcinoma

\begin{tabular}{lrrr}
\hline & Telomerase & COX-2 & \multicolumn{1}{c}{$p 53$} \\
\hline Mann-Whitney $U$ & 75.500 & 82.00 & 58.500 \\
Wilcoxon $W$ & 375.500 & 382.000 & 358.500 \\
$Z$ & -3.732 & -3.448 & -3.933 \\
Asymp.sig. (two-tailed) & 0.001 & 0.001 & 0.000 \\
\hline
\end{tabular}

and regressing keratoacanthoma with squamous cell carcinoma and found that oncostatin $M$ is not a specific marker that is useful for distinction of keratoacanthoma from squamous cell carcinoma. Tran et $a l^{12}$ also compared mitotic cyclins and cyclin-dependent kinase expression in keratoacanthoma and squamous cell carcinoma and indicated a role for mitotic cyclins in the development of keratoacanthoma and squamous cell carcinoma, but do not recommend them as markers for distinguishing keratoacanthoma from squamous cell carcinoma. Expression of desmosomal glycoproteins was evaluated by Krunic et $a l^{10,11}$ and recommended their potential value in differentiating keratoacanthoma from squamous cell carcinoma. They found that all their keratoacanthoma cases showed extensive pericellular immunohistochemical staining for desmoglein. By contrast, squamous cell carcinoma had diminished or complete absence of staining. Syndecan-1, a heparan sulfate proteoglycan that mediates intercellular and cell to matrix adhesion, was also a basis to distinguish keratoacanthoma from squamous cell carcinoma. A higher expression was noted in keratoacanthoma compared to significantly diminished staining in squamous cell carcinoma. ${ }^{15}$ They postulated that retention of syndecan-1 expression might explain for its noninvasive behavior. In another study, sialyl-Tn, a cell surface carbohydrate was expressed significantly higher in keratoacanthoma than in squamous cell carcinoma, leading to a hypothesis that Sialyl-Tn expression is associated with tumor regression as seen in keratoacanthoma. ${ }^{14}$

Clausen et $a l^{17}$ used comparative genomic hybridization, a technique that allows simultaneous detection of amplified or deleted chromosomal regions of the total genome of neoplasms, to differentiate keratoacanthoma from squamous cell carcinoma. They found that most frequently occurring chromosomal aberrations in keratoacanthomas were not detected in the analyzed squamous cell carcinomas, indicating genetic disparities between these two entities. Studies on proliferating cell nuclear antigen (PCNA) and $\mathrm{Le}^{\mathrm{Y}}$ expression also indicated some differences between them. ${ }^{9}$ In keratoacanthoma, PCNA expression was limited to basal and suprabasal layers while $\mathrm{Le}^{\mathrm{Y}}$ was seen in diffuse pattern. In contrast, squamous cell carcinoma cases had diffuse PCNA expression and absence of $\mathrm{Le}^{\mathrm{Y}}$ in the basal layer. In a related study evaluating the role of telomerase activity, PCNA and p53 in cervical intraepithelial neoplasia, the investigators found that the level of telomerase activity, PCNA and p53 was significantly related to the grade of dysplasia. ${ }^{28}$ They observed a sequential increase in the parameters, signaling the progression of abnormality. These findings can be extrapolated to our study, which demonstrated an increase in p53 and telomerase activity from keratoacanthoma to squamous cell carcinoma. The findings once again reiterate the relationship between keratoacanthoma and squamous cell carcinoma. In a related article, mutant p53 oncoprotein expression was studied in a 
few cases of keratoacanthoma and squamous cell carcinoma showed a significant trend in p53 positivity from keratoacanthoma to squamous cell carcinoma; however, it was concluded that p53 expression of its own accord is inadequate for a clear distinction between them. ${ }^{8}$ Kerschmann et $a l^{7}$ also did not find p53 expression as a useful marker for differentiating keratoacanthoma from squamous cell carcinoma. They concluded that a majority of keratoacanthoma and squamous cell carcinoma contain p53 protein but with a variable distribution. In keratoacanthoma, the p53 expression was confined to basal layers, in contrast to diffuse pattern in squamous cell carcinoma. Mutation studies of p53 gene confirm a higher incidence of mutations in squamous cell carcinoma, in contrast to keratoacanthoma. ${ }^{25,26}$ They found no correlation between immunohistochemical detection of p53 oncoprotein and gene mutations, and recommend sequence analysis to determine gene mutation. From the above studies, it appears that although immunohistochemical determination is helpful, sequence analysis of $p 53$ gene is essential to identify the mutation.

Taylor et $a l^{29}$ have studied telomerase activity in few malignant (basal cell carcinoma, squamous cell carcinoma, and melanoma) and nonmalignant skin conditions. They found that sun-damaged skin has a higher telomerase activity than sun-protected areas, although much less than that detected in tumors and postulate that environmental factors may modulate telomerase activity. $\mathrm{Wu}$ et $a l^{30}$ reported on the expression of telomerase subunits in various human skin tumors and in normal skin samples. They concluded that among the three subunits, the human telomerase catalytic subunit has strong correlation with the activation of telomerase in skin tumors. Rudolph et $a{ }^{31}$ assayed telomerase activity in a variety of melanocytic lesions such as simple lentigos, nevi and various stages of malignant melanomas. Their results suggest that telomerase assays may help to elicit early malignant transformation that is undetectable by conventional morphology.

Our results show the presence of telomerase activity in both squamous cell carcinoma and keratoacanthoma, but a significant higher expression is present in squamous cell carcinoma compared to keratoacanthoma (' $P$ ' value 0.001 ). This differential expression might explain the sustained proliferation seen in squamous cell carcinoma vs the shorter lifespan and involution in keratoacanthoma. Traditionally, telomerase activity is measured by cumbersome molecular techniques based on polymerase chain reaction requiring fresh frozen tissues or cells, but recently a telomerase RNA probe that specifically hybridizes to the RNA component of human telomerase in formalin-fixed, paraffinembedded tissue, has been introduced. With this technique, specificity problems associated with nonmorphology-preserving methods such as
Telomeric repeat amplification protocol (TRAP) assay can be avoided. Recently, Yoo et $a l^{32}$ published their results of telomerase activity in human softtissue sarcomas utilizing in situ hybridization technique. The wide spread use of telomerase activity as a prognostic marker and as a target marker for chemotherapy efficiency in several human malignancies facilitates a further understanding of telomerase biology, potentially leading to diagnostic and therapeutic applications. With the advent of a monoclonal antibody to human telomerase reverse transcriptase activity, applicable to formalin-fixed paraffin-embedded tissue, a wide range of archival specimens can be studied and also can be readily applied to routine histopathology practice.

Chan et $a l^{23}$ demonstrated several fold increase in mean levels of COX-2 mRNA in squamous cell carcinoma compared with normal oral mucosa from healthy volunteers. Immunohistochemical analysis also showed stronger expression in squamous cell carcinoma compared to minimal expression in normal appearing epithelium adjacent to squamous cell carcinoma. Upregulated COX-2 enhances prostaglandin synthesis, which in turn increases cell proliferation, promotes angiogenesis, inhibits immunosurveillance, and also enhances invasiveness. ${ }^{33}$ In our study, minimal COX-2 expression correlates with a general lack of invasive features in keratoacanthoma.

Overexpression of COX-2 is the basis for alternative treatment regimens using nonsteroidal antiinflammatory agents (NSAIDs). In a study testing the influence of NSAIDs on cells lines from squamous cell carcinoma and normal oral mucosal keratinocytes, the neoplastic cell lines showed a reduction in cell numbers, decrease in telomerase activity, and increased cells in G0/G1 phase, whereas normal keratinocytes had minimal effects. ${ }^{34}$

In conclusion, the different histological criteria commonly utilized in differentiation of keratoacanthoma from squamous cell carcinoma are not entirely reliable. This differentiation is clinically relevant as typical keratoacanthoma lesions have potential to involute spontaneously without treatment and also to avoid major surgical and therapeutic procedures generally reserved for squamous cell carcinoma. A controversy of whether keratoacanthoma represents a well-differentiated form of squamous cell carcinoma still persists. Our study utilizing telomerase activity, COX-2, and p53 expression in combination proved that they are definitely helpful in discriminating most keratoacanthomas from squamous cell carcinoma, which closely resemble each other on conventional morphology and also explain the biologic variation between them. True immortality in a genuine squamous cell carcinoma is conferred by a combined action of p53 mutation, and higher expression of COX-2 and telomerase activity. The lower expression of these factors leads to a limited extension of lifespan in keratoacanthoma, followed 
by a crisis phase, characterized by cell death and involution. Although the markers present new insights into the biologic behavior of keratoacanthoma and squamous cell carcinoma, they are of only limited value for distinction of the two lesions in routine surgical pathology. There is a need for further research to study the molecular mechanisms involved in biologic variations between keratoacanthoma and squamous cell carcinoma.

\section{Acknowledgements}

This work was supported by a research grant from National Medical Research Council, Singapore. We thank Mr Shahul H Maricar, NUS and Mr Tan Tee Chok, NUS for excellent technical support. This paper was presented as a poster at the 92nd annual scientific meeting of the United States and Canadian Academy of Pathology, held between 22 and 28 March 2003, in Washington, DC, USA.

\section{References}

1 Elders J. Lever's Histopathology of Skin, 8th ed. Lippincott-Raven: Philadelphia, NY, 1997.

2 Ackerman AB, Mendonca AMN, Guo Y. Keratoacanthoma vs squamous cell carcinoma. In: Differential Diagnosis in Dermatopathology I, 2nd ed. Lea \& Febiger: Philadelphia/London, 1992.

3 LeBoit PE. Is keratoacanthoma a variant of squamous cell carcinoma? New insights into an old controversy... soon? Am J Dermatopathol 1995;4:319-320.

4 Rook A, Whimster I. Keratoacanthoma-A thirty-year retrospect. Br J Dermatol 1979;100:41-47.

5 Cribier B, Asch P-H, Grosshans E. Differentiating squamous cell carcinoma from keratoacanthoma using histopathological criteria. Is it possible? A study of 296 cases. Dermatology 1999;199:208-212.

6 Pilch H, Weiss J, Heubner C, et al. Differential diagnosis of keratoacanthomas and squamous cell carcinomas: diagnostic value of DNA image cytometry and p53 expression. J Cutan Pathol 1994;21:507-513.

7 Kerschmann RL, McCalmont TH, LeBoit PE. p53 oncoprotein expression and proliferation index in keratoacanthoma and squamous cell carcinoma. Arch Dermatol 1994;130:181-186.

8 Stephenson TJ, Royds J, Silcocks PB, et al. Mutant p53 oncogene expression in keratoacanthoma and squamous cell carcinoma. Br J Dermatol 1992;127:566-570.

9 Tsuji T. Keratoacanthoma and squamous cell carcinoma: study of PCNA and Le(Y) expression. J Cutan Pathol 1997;24:409-415.

10 Krunic ALJ, Garrod DR, Smith NP, et al. Differential expression of desmosomal glycoproteins in keratoacanthoma and squamous cell carcinoma of the skin: An immunohistochemical aid to diagnosis. Acta Derm Venereol 1996;76:394-398.

11 Krunic AL, Garrod DR, Madani S, et al. Immunohistochemical staining for desmogleins 1 and 2 in keratinocytic neoplasms with squamous phenotype; actinic keratosis, keratoacanthoma and squamous cell carcinoma of skin. Br J Cancer 1998;77:1275-1279.
12 Tran TA, Ross JS, Boehm JR, et al. Comparison of mitotic cyclins and cyclin dependent kinase expression in keratoacanthoma and squamous cell carcinoma. J Cutan Pathol 1999;26:391-397.

13 Tran TA, Ross JS, Sheehan CE, et al. Comparison of Oncostatin M expression in keratoacanthoma and squamous cell carcinoma. Mod Pathol 2000;13: 427-432.

14 Jensen P, Clausen OP, Bryne M. Differences in sialyl-Tn antigen expression between keratoacanthomas and cutaneous squamous cell carcinomas. J Cutan Pathol 1999;26:183-189.

15 Mukunyadzi P, Sanderson RD, Fan CY, et al. The level of syndecan-1 expression is a distinguishing feature in behavior between keratoacanthoma and invasive cutaneous squamous cell carcinoma. Mod Pathol 2002;15:45-49.

16 Takedo H, Kondo S. Differences between squamous cell carcinoma and keratoacanthoma in angiotensin type-1 receptor expression. Am J Pathol 2001;158: 1633-1637.

17 Clausen OP, Beigi M, Bolund L, et al. Keratoacanthomas frequently show chromosomal aberrations as assessed by comparative genomic hybridization. J Invest Dermatol 2002;119:1367-1372.

18 Kim NW, Piatyszek MA, Prowse KR, et al. Specific association of human telomerase activity with immortal cells and cancer. Science 1994;266:2011-2015.

19 Rhyu MS. Telomeres, telomerase and immortality. J Nat Cancer Inst 1995;87:884-894.

20 Shay JW, Bacchetti S. A survey of telomerase activity in human cancer. Eur J Cancer 1997;33:787-791.

21 Williams CS, Tsujii M, Reese J, et al. Host cyclooxygenase-2 modulates carcinoma growth. J Clin Invest 2000;105:1589-1594.

22 Gately S. The contributions of cyclooxygenase-2 to tumor angiogenesis. Cancer Metast Rev 2000;19:19-25.

23 Chan G, Boyle JO, Yang EK, et al. Cyclooxygenase-2 expression is up-regulated in squamous cell carcinoma of the head and neck. Cancer Res 1999;59:991-994.

24 Harris AL. Mutant p53-the commonest genetic abnormality in human cancer? J Pathol 1990;162:5-6.

25 Kubo Y, Urano Y, Yoshimoto K, et al. p53 gene mutations in human skin cancers and precancerous lesions: comparison with immunohistochemical analysis. J Invest Dermatol 1994;102:440-444.

26 Perez MI, Robins P, Biria S, et al. P53 oncoprotein expression and gene mutations in some keratoacanthomas. Arch Dermatol 1997;Feb:133:189-193.

27 Hodak E, Jones RE, Ackerman AB. Solitary keratoacanthoma is a squamous-cell carcinoma: three examples with metastases. Am J Dermatopathol 1993; 4:332-342.

28 Herbsleb M, Knudsen UB, Orntoft TF, et al. Telomerase activity, MIB-1, PCNA, HPV-16 and p53 as diagnostic markers for cervical intraepithelial neoplasia. APMIS 2001;109:607-617.

29 Taylor RS, Ramirez RD, Ogoshi M, et al. Detection of telomerase activity in malignant and non-malignant skin conditions. J Invest Dermatol 1996;106:759-765.

$30 \mathrm{Wu} \mathrm{A}$, Ichihashi M, Ueda M. Correlation of the expression of human telomerase subunits with telomerase activity in normal and skin tumors. Cancer 1999;86:2038-2044.

31 Rudolph P, Schubert C, Tamm S, et al. Telomerase activity in melanocytic lesions; a potential marker of tumor Biology. Am J Pathol 2000;156:1425-1432. 
32 Yoo K, Robinson RA. Expression of telomerase activity and telomerase RNA in human soft tissue sarcomas. Arch Pathol Lab Med 2000;124: 393-397.

33 Tsujii M, Kawano S, DuBois RN. Cyclooxygenase-2 expression in human colon cancer cells increases metastatic potential. Proc Natl Acad Sci USA 1997;94:3336-3340.

34 Thumher D, Bakroeva M, Formanek M, et al. Nonsteroidal anti-inflammatory drugs inhibit telomerase activity in head and neck squamous carcinoma cell lines. Head Neck 2001;23:1049-1055. 